\title{
Effect of dietary sodium phytate and microbial phytase on the lipase activity and lipid metabolism of broiler chickens
}

\author{
Ning $\mathrm{Liu}^{1} *$, Yingjun $\mathrm{Ru}^{2}$, Jianping $\mathrm{Wang}^{1}$ and Tingsheng $\mathrm{Xu}^{1}$ \\ ${ }^{1}$ School of Livestock Science, Henan University of Science and Technology, Luoyang 471003, China \\ ${ }^{2}$ Danisco Animal Nutrition, East Wing Singapore Science Park III, Singapore 117525
}

(Received 22 April 2009 - Revised 22 September 2009 - Accepted 23 September 2009 - First published online 10 December 2009)

\begin{abstract}
The objective of the present study was to investigate the effect of dietary phytate and microbial phytase on the lipase activity, lipid metabolism and mRNA expressions of fatty acid synthase (FASN) and leptin in broiler chickens. The study was conducted as a $2 \times 3$ factorial arrangement of treatments with phytate phosphorus at 0.20 and $0.40 \%$ (added as the sodium phytate) and supplemental microbial phytase at 0 , 500, or 1000 phytase units $/ \mathrm{kg}$. The results showed that phytase improved $(P<0.05)$ the growth performance and ileal digestibility of nutrients of broilers, but phytate had no effect $(P>0.05)$ on these parameters, except the decrease $(P<0.01)$ in the digestibility of Ca. Phytate decreased $(P<0.05)$ the lipase activity, serum total cholesterol (T-CHO) and hepatic TAG, and elevated $(P<0 \cdot 01)$ serum NEFA and HDL cholesterol. Phytase decreased $(P<0.05)$ serum NEFA, but increased $(P<0.01)$ serum T-CHO and hepatic TAG. Phytate and phytase also influenced $(P<0.01)$ the mRNA expressions of leptin in the liver. There were significant $(P<0.05)$ interactions of phytate and phytase on the concentrations of serum TAG and LDL cholesterol, hepatic NEFA and T-CHO, and the mRNA expressions of FASN. The results suggest that phytate and phytase can affect lipase activity and lipid metabolism of broiler chickens.
\end{abstract}

Chickens: Lipase: Lipid metabolism: Phytase: Phytate

Dietary phytate and phytase can exert a physiological effect on the digestion processes of carbohydrate and protein by modifying endogenous secretion and nutrient transport in the gastrointestinal tract of chickens ${ }^{(1-3)}$. Similarly, lipid digestion and deposition in the body may also be affected by the ingestion of phytate and phytase in animals. It is reported that dietary phytate or inositol phosphate ester fractions inhibited the in vitro activity of lipase ${ }^{(4)}$, and lipid digestibility, blood lipid concentration and hepatic lipogenesis in mice or rats ${ }^{(5-7)}$. The matrix value of phytase in the improvement of dietary energy has recently been reported in chickens ${ }^{(8,9)}$. However, the extant literature is limited about the effect of phytate and phytase on the fat digestion in chickens. Only Camden et al. ${ }^{\left({ }^{(0)}\right.}$ reported that microbial phytase significantly increased the digestibility of fat of broiler starters.

The changes of circulating factors, metabolic products or nutrient stores in the body caused by dietary composition can be physiological signals to affect feed intake and energy balance via the peripheral and central nervous systems ${ }^{(11)}$. Due to fat being the least readily metabolised macronutrient, signals relating to fat status largely appear to arise in the periphery. Given dietary phytate depressing the utilisation of energy of chickens ${ }^{(8)}$, it would be reasonable to hypothesise that dietary phytate directly or indirectly affects peripheral signals in the context of energy balance of broiler chickens.

The objective of the present study was to investigate the effect of dietary phytate and phytase supplementation on the apparent ileal digestibility of fat, activity of lipase in the pancreas and intestine, mRNA expressions of fatty acid synthase (FASN) and leptin in the liver, and lipid metabolism in serum and liver of broiler chickens.

\section{Materials and methods}

\section{Diets and chickens}

The experiment was conducted as a $2 \times 3$ factorial arrangement of treatments based on maize-soyabean meal diets with the levels of phytate phosphorus at 0.20 or $0.40 \%$ and the addition of Escherichia coli-derived phytase (Phyzyme XP; Danisco Animal Nutrition, Marlborough, Wiltshire, UK) at 0,500 or 1000 phytase units $/ \mathrm{kg}$ diet. Sodium phytate (Shanghai Bangcheng Chemical Co., Jiading, Shanghai, China) was used to manipulate phytate phosphorus content in the high phytate diet. Titanium dioxide was added at $0.50 \%$ as the indigestible marker in the finisher diet. The compositions of starter and finisher diets are listed in Table 1.

Experimental birds were handled with care to avoid unnecessary discomfort, and all procedures were approved by Henan University of Science and Technology Animal Care and Use Committee. A total of 504 broilers (1-d-old; Cobb 500) were randomly allocated into six treatments, each of which had six replicate cages of fourteen chicks per cage. All chicks were raised in three-tiered cages (per cage 
Table 1. Compositions of two basal diets (\%)

\begin{tabular}{|c|c|c|c|c|}
\hline \multirow[b]{2}{*}{ Ingredients } & \multicolumn{2}{|c|}{ Starter period } & \multicolumn{2}{|c|}{ Finisher period } \\
\hline & Low phytate & High phytate & Low phytate & High phytate \\
\hline Maize & 64.50 & 64.50 & 59.83 & 59.83 \\
\hline Soyabean meal & $16 \cdot 40$ & $16 \cdot 40$ & $24 \cdot 60$ & $24 \cdot 60$ \\
\hline Cottonseed meal & $9 \cdot 30$ & $9 \cdot 30$ & 0 & 0 \\
\hline Maize gluten meal & 0 & 0 & 4.00 & 4.00 \\
\hline Dried distillers grains with solubles & 0 & 0 & 4.60 & 4.60 \\
\hline Maize germ meal & 0 & & $2 \cdot 30$ & $2 \cdot 30$ \\
\hline Fish meal & 4.40 & 4.40 & 0 & 0 \\
\hline Limestone & 1.45 & 1.45 & 1.60 & 1.60 \\
\hline Dicalcium phosphate & 0.05 & 0.05 & 0 & 0 \\
\hline Salt & 0.36 & 0.36 & 0.36 & 0.36 \\
\hline Natural synthetic oils & 1.35 & 1.35 & 0 & 0 \\
\hline Mineral/vitamin premix ${ }^{*}$ & 1.00 & 1.00 & 1.00 & 1.00 \\
\hline Met & 0.06 & 0.06 & 0.12 & $0 \cdot 12$ \\
\hline Thr & 0 & 0 & 0.09 & 0.09 \\
\hline Lys & 0.13 & $0 \cdot 13$ & 0 & 0 \\
\hline Zeolite & 1.00 & 0 & 1.00 & 0 \\
\hline Sodium phytate & 0 & 1.00 & 0 & 1.00 \\
\hline Titanium dioxide & 0 & 0 & 0.50 & 0.50 \\
\hline \multicolumn{5}{|l|}{ Nutrient level } \\
\hline Crude protein & 21.08 & 21.08 & $20 \cdot 14$ & $20 \cdot 14$ \\
\hline Metabolisable energy (MJ/kg) & $12 \cdot 13$ & $12 \cdot 13$ & 11.92 & 11.92 \\
\hline Crude fat & 3.55 & 3.55 & 3.51 & 3.51 \\
\hline Crude fibre & 3.33 & 3.33 & 3.53 & 3.53 \\
\hline $\mathrm{Ca}$ & 0.79 & 0.79 & 0.70 & 0.70 \\
\hline Total P & 0.50 & $0 \cdot 70$ & 0.48 & 0.68 \\
\hline Phytate phosphorus & $0 \cdot 20$ & 0.40 & 0.20 & 0.40 \\
\hline Met & 0.46 & 0.46 & 0.45 & 0.45 \\
\hline Met + Cys & 0.83 & 0.83 & 0.70 & 0.70 \\
\hline Lys & 1.05 & 1.05 & 0.90 & 0.90 \\
\hline
\end{tabular}

$1.0 \mathrm{~m} \times 1.8 \mathrm{~m})$ and given ad libitum access to diet and water, continuous lighting, controlled ventilation. Temperature was maintained at $32^{\circ} \mathrm{C}$ for the first week and then gradually reduced until a temperature of $22^{\circ} \mathrm{C}$ was achieved at the fourth week. Body weight and diet consumption per cage basis were recorded weekly. At 7 and $21 \mathrm{~d}$ of age, the chickens were inoculated with Newcastle disease virus and infectious bronchitis vaccines (Yikang Biological Products Co., Taizihe, Liaoyang, China) by intranasal and intraocular administration, respectively.

\section{Sample preparation}

At day 42 of age, before sampling, the birds were offered diets and water as usual. Six birds per replicate were randomly selected and blood was obtained by cardiac puncture and directly aliquoted into a 2-ml sterile vial allowed to clot for $4 \mathrm{~h}$ for serum preparation. After centrifugation for $10 \mathrm{~min}$ at $3000 \mathrm{~g}$, the serum was aliquoted $(100 \mu \mathrm{l})$ into $1-\mathrm{ml}$ vials and stored at $-20^{\circ} \mathrm{C}$ for measurements. Then, the birds were euthanised by simultaneous electrocution on the heart and left and right brains. Two fragments from the same position of chicken liver were collected, combined by replicate. One was frozen in liquid nitrogen, and kept at $-70^{\circ} \mathrm{C}$ for mRNA assay. Another was kept at $-20^{\circ} \mathrm{C}$ for the assay of lipid metabolites. Duodenum and jejunum were separated, and washed with $0-4^{\circ} \mathrm{C}$ sodium chloride solution $(0.15 \mathrm{~mol} / \mathrm{l})$ to remove any digesta. The lumen of duodenum and jejunum was cut longitudinally to expose brush border cells. Mucosa was gently scraped off with a glass microscope slide and pooled by replicate. The supernatant samples of intestinal mucosa and liver fragments were prepared as the description by Liu et al. ${ }^{(2)}$. The pooling of samples by replicate is a means of normalising individual differences in enzyme activity and gene expression analysis. A section of ileum was removed by cutting from the Meckel's diverticulum to the ileocaecal junction. A $50 \mathrm{ml}$ syringe full of room temperature deionised water was inserted into one end of the ileum and carefully flushed out the digesta of the gut into a $10 \mathrm{~cm}$ diameter Petri dish. The digesta of each replicate was pooled and freeze-dried for laboratory analysis. The content of titanium dioxide in sample was determined according to the method of Short et al. ${ }^{(12)}$. Total phosphorus, $\mathrm{Ca}$, crude protein and crude fat in the sample were determined according to the Association of Official Analytical Chemists (1990) methods 964.06, 935.13, 976.05 and 920.39, respectively. Phytate phosphorus was estimated by extraction of phytate with $15 \%$ TCA as described by Maga ${ }^{(13)}$. Gross energy was measured by Oxygen Bomb Calorimeter (Model 6100; PARR, Moline, IL, USA). DM was determined by drying $2 \mathrm{~g}$ sample at $70^{\circ} \mathrm{C}$ to a constant mass. The apparent ileal digestibility of nutrients and ileal digestible energy were calculated as described by Camden et al. ${ }^{(10)}$. 


\section{Enzyme activity assay}

The activity of lipase (EC 3.1.1.3) was measured following the method of Iijima et al. ${ }^{(14)}$ without the procedure of enzyme activation by bile salts in the intestine. In a microcentrifuge tube, $287 \mu \mathrm{l}$ of $5.2 \mathrm{mmol} / \mathrm{l}$ sodium cholate dissolved in $250 \mathrm{mmol} / \mathrm{l}$ Tris (2-amino-2-(hydroxymethyl)-1,3-propanediol) hydrochloride ( $\mathrm{pH} 9.0$ ) was combined with $20 \mu$ l homogenate and $18 \mu \mathrm{l}$ of $10 \mathrm{mmol} / \mathrm{l}$ substrate $p$-nitrophenyl myristate (No 70 124; Sigma-Aldrich, Bellefonte, PA, USA) dissolved in $100 \%$ ethanol and incubated at $15^{\circ} \mathrm{C}$ for $2 \mathrm{~h}$, after which time the reaction was stopped with $467 \mu$ l acetone-heptane $(5: 2, \mathrm{v} / \mathrm{v})$. The samples were then centrifuged at $6100 \mathrm{~g}$ for $2 \mathrm{~min}$. The resulting lower aqueous layer was read at $405 \mathrm{~nm}$ and the activity was determined using a $p$-nitrophenol (No 35 836; Sigma-Aldrich) standard curve. Lipase activity was expressed as $\mu$ mol per gram protein $(1 \mathrm{nmol} p$-nitrophenol liberated per min). Mucosa and liver protein concentrations were determined by the method of Lowry et al. ${ }^{(15)}$.

\section{Lipid metabolite assay}

Concentrations of total protein, NEFA, HDL cholesterol (HDLC), LDL cholesterol, total cholesterol (T-CHO) and TAG in the serum or liver were measured with commercial assay kits (Beijing BHKT Clinical Reagent Co., Tongzhou, Beijing, China). Samples from mucosa or liver were pooled by replicate before measurement. Serum samples were measured individually, and the average of six birds per replicate was considered as the statistical unit. All measurements for each variable were run in the same assay to avoid interassay variability. Results of parameters in serum were expressed as units per $\mathrm{ml}$ serum, and in mucosa as units per milligram protein.

\section{Messenger RNA quantification}

The mRNA expression of FASN and leptin in the liver was analysed by real-time PCR. The procedures of total RNA preparation and reverse transcription PCR were described in Liu et al. ${ }^{(2)}$. Primers were designed according to the reported sequences (Table 2). Primer specificity was checked by systematic sequencing of PCR products. Quantification of different mRNAs was performed on iCycler iQ Real-Time PCR Detection System (Bio-Rad, Hercules, CA, USA) using SYBR Premix Ex TaqTM (TaKaRa; Dalian, Liaoning, China), and the reaction conditions were as follows: $94^{\circ} \mathrm{C}$ for $90 \mathrm{~s}, 35$ cycles at $95^{\circ} \mathrm{C}$ for $30 \mathrm{~s}$ and $65^{\circ} \mathrm{C}$ for $1 \mathrm{~min}$. Melt curves were used to monitor product specificities. Plasmid

Table 2. Primer pairs used to quantify gene expression in the liver of broiler chickens

\begin{tabular}{cll}
\hline Gene & Primer pair & NCBI RefSeq (position) \\
\hline Leptin & 5'-GTGCTGCAGATAGCCAATGA-3' $^{\prime}$ & AF012727 (268-485) \\
& $5^{\prime}$-TCCGGGCTAATATCCAACTG-3' & \\
FASN & $5^{\prime}$-GTGTTCGTGACGTGAGCAGT-3' & NM205155 (6225-6414) \\
& $5^{\prime}$-TCCTCTGCTGTCCCAGTCTT-3' & \\
3-Actin & 5'-CTCCCTGATGGTCAGGTCAT-3' $^{\prime}$ & NM205518 (732-934) \\
& 5'-ATGCCAGGGTACATTGTGGT-3' $^{\prime}$ & \\
\hline
\end{tabular}

FASN, fatty acid synthase. prepared from sample amplicon was diluted in fivefold dilution steps covering the expected detection range of target genes and reference gene for generating standard curves. Samples and plasmids were simultaneously assayed in duplicate. The quantification of mRNA expression was normalised to $\beta$-actin.

\section{Statistical analysis}

Two-way ANOVA was employed to determine the main effects of phytate and phytase and their interaction by using the GLM procedure of Statistical Analysis System version 9.0 (SAS Institute, Cary, NC, USA) using cage as the experimental unit. One-way ANOVA was used to compare the differences among treatments. Copies of target genes were normalised to $\beta$-actin copies. Differences were considered significant using Duncan's multiple range test at $P<0.05$. Values in the tables were means and pooled SEM.

\section{Results}

For broiler starters, sodium phytate had no effect $(P>0.05)$ on the feed intake, but increased $(P<0.05)$ the feed per gain (Table 3). Microbial phytase increased $(P<0 \cdot 01)$ the feed intake and decreased $(P<0 \cdot 01)$ the feed per gain of starters. There was an interaction $(P<0.05)$ of phytate and phytase on the body weight gain of starters. For broiler finishers, microbial phytase increased $(P<0.05)$ the feed intake and body weight gain, except for the feed per gain. During the whole period, phytase improved $(P<0 \cdot 01)$ the growth performance of broilers, whereas sodium phytate was without any effect $(P>0.05)$. Increasing phytase dose from 500 to 1000 phytase units $/ \mathrm{kg}$ improved $(P<0.05)$ the body weight gain and decreased $(P<0.05)$ the feed per gain of starters. The diet containing sodium phytate decreased $(P<0.05)$ the body weight gain compared with the low phytate diet when no phytase was added for starters.

Sodium phytate decreased $(P<0.01)$ the ileal digestibility of $\mathrm{Ca}$, but had no effect $(P>0.05)$ on the digestibilities of other parameters for broiler finishers (Table 4). Microbial phytase increased $(P<0.01)$ the digestibilities of DM, crude protein, energy, crude fat, $\mathrm{Ca}, \mathrm{P}$ and phytate $\mathrm{P}$. Sodium phytate lowered $(P<0.05)$ the digestibility of crude fat $(82.7$ $v$. $80.5 \%$ ) when no phytase was added. The interaction of phytate and phytase on the digestibility of crude protein was significant $(P<0 \cdot 01)$. Increasing phytase doses improved $(P<0.05)$ the digestibilities of crude protein, $\mathrm{Ca}$ and phytate $\mathrm{P}$ of broilers.

Sodium phytate depressed $(P<0.05)$ the activity of lipase by $7-20 \%$ in the pancreas or small intestine of broiler finishers, whereas phytase was without any effect $(P>0.05)$ on this parameter (Table 5). The relative weights of pancreases were higher $(P<0.01)$ for broilers fed diets with phytase addition. No significant interactions $(P>0.05)$ were observed on the activity of lipase and the relative weight of pancreas. The effects of phytase doses also had no significance $(P>0.05)$ on these parameters. In the pancreas and duodenum, diets with high phytate $\mathrm{P}$ depressed $(P<0.05)$ the activity of lipase when no phytase was added.

In the serum, sodium phytate increased $(P<0 \cdot 01)$ the concentrations of NEFA and HDLC by 38 and $5 \%$, respectively, 
Table 3. Effect of phytate and phytase on the growth performance of broiler chickens

\begin{tabular}{|c|c|c|c|c|c|c|c|c|c|c|}
\hline \multicolumn{2}{|l|}{ Treatment* } & \multicolumn{3}{|c|}{ Starter period } & \multicolumn{3}{|c|}{ Finisher period } & \multicolumn{3}{|c|}{ Whole period } \\
\hline Phytate P (\%) & Phytase (FTU/kg) & $\mathrm{FI}(\mathrm{g})$ & BWG (g) & FI:BWG & $\mathrm{FI}(\mathrm{g})$ & BWG (g) & FI:BWG & $\mathrm{FI}(\mathrm{g})$ & BWG (g) & FI:BWG \\
\hline 0.20 & 0 & 910 & 602 & 1.51 & 3158 & 1510 & $2 \cdot 10$ & 4068 & 2112 & 1.93 \\
\hline 0.20 & 500 & 982 & 675 & 1.46 & 3301 & 1611 & 2.08 & 4283 & 2286 & 1.88 \\
\hline 0.20 & 1000 & 988 & 707 & 1.40 & 3262 & 1615 & 2.02 & 4250 & 2323 & 1.83 \\
\hline 0.40 & 0 & 895 & 585 & 1.53 & 3166 & 1461 & $2 \cdot 17$ & 4061 & 2046 & 1.99 \\
\hline 0.40 & 500 & 992 & 683 & 1.45 & 3276 & 1580 & 2.08 & 4268 & 2263 & $1 \cdot 89$ \\
\hline 0.40 & 1000 & 1017 & 708 & 1.44 & 3082 & 1536 & $2 \cdot 02$ & 4099 & 2243 & 1.83 \\
\hline $\begin{array}{l}\text { SEM } \\
\text { Main effectt }\end{array}$ & & $8 \cdot 91$ & $4 \cdot 30$ & 0.02 & $53 \cdot 31$ & $38 \cdot 34$ & 0.05 & $42 \cdot 76$ & $41 \cdot 21$ & 0.03 \\
\hline \multicolumn{11}{|l|}{ Phytate P } \\
\hline $0 \cdot 20$ & & 960 & 661 & 1.46 & 3240 & 1579 & $2 \cdot 07$ & 4200 & 2240 & 1.88 \\
\hline 0.40 & & 968 & 659 & 1.47 & 3175 & 1526 & 2.09 & 4143 & 2184 & 1.90 \\
\hline$P \leq$ & & NS & NS & 0.026 & NS & NS & NS & NS & NS & NS \\
\hline \multicolumn{11}{|l|}{ Phytase } \\
\hline 0 & & 903 & 594 & 1.52 & 3162 & 1486 & 2.14 & 4065 & 2079 & 1.96 \\
\hline 500 & & 987 & 679 & 1.46 & 3289 & 1596 & 2.08 & 4276 & 2275 & $1 \cdot 89$ \\
\hline 1000 & & 1003 & 708 & 1.42 & 3172 & 1576 & 2.02 & 4175 & 2283 & 1.83 \\
\hline$P \leq$ & & 0.001 & 0.001 & 0.001 & 0.044 & 0.017 & NS & 0.002 & 0.001 & 0.001 \\
\hline \multicolumn{11}{|c|}{ Phytase $\times$ phytate } \\
\hline$P \leq$ & & NS & 0.021 & NS & NS & NS & NS & NS & NS & NS \\
\hline
\end{tabular}

FTU, phytase units; FI, feed intake; BWG, body weight gain; NS, $P \geq 0.05$.

${ }^{*} n 6$ per treatment.

† Data involving 0.20 or $0.40 \%$ phytate phosphorus with 0,500 or $1000 \mathrm{FTU} / \mathrm{kg}$ microbial phytase were analysed as a $2 \times 3$ factorial arrangement of treatments.

and decreased $(P<0 \cdot 01)$ T-CHO by $8 \%$ (Table 6$)$. Phytase decreased $(P<0.05)$ NEFA by $15 \%$, but increased $(P<0.01)$ $\mathrm{T}-\mathrm{CHO}$ by $12 \%$. The interactions of phytate and phytase on the concentrations of TAG and LDL cholesterol were significant $(P<0 \cdot 01)$. Phytate $\mathrm{P}$ content significantly influenced $(P<0.05)$ the concentrations of NEFA, HDLC and TAG in the serum when no phytase was added.

In the liver, phytate had no effect $(P>0.05)$ on the concentrations of TAG and T-CHO (Table 6). Phytase increased $(P<0.01)$ TAG concentration by $14 \%$. The interactions of phytate and phytase on the concentrations of NEFA
$(P<0.01)$ and T-CHO $(P<0.05)$ in the liver were significant, indicating that the responses in the concentrations of lipid metabolites with supplemental phytase varied at different dietary phytate levels. A significant difference $(P<0 \cdot 01)$ was observed in the concentration of NEFA in the liver between birds fed diets with 0.20 and $0.40 \%$ phytate $\mathrm{P}$ without phytase. Increasing the phytase doses decreased $(P<0 \cdot 01)$ the concentrations of NEFA and T-CHO in the low phytate basal diets.

The mRNA expression of leptin was up-regulated $(P<0 \cdot 01)$ by phytate, and down-regulated $(P<0 \cdot 01)$ by phytase

Table 4. Effect of phytate and phytase on the apparent ileal digestibility of nutrients and ileal DE of broiler chickens

\begin{tabular}{|c|c|c|c|c|c|c|c|c|}
\hline \multicolumn{9}{|l|}{ Treatment $^{\star}$} \\
\hline Phytate P (\%) & Phytase (FTU/kg) & DM (\%) & CP (\%) & $\mathrm{DE}(\mathrm{MJ} / \mathrm{kg})$ & EE (\%) & $\mathrm{Ca}(\%)$ & $\mathrm{P}(\%)$ & Phytate P (\%) \\
\hline 0.20 & 0 & 78.67 & $75 \cdot 67$ & $13 \cdot 58$ & $82 \cdot 65$ & $58 \cdot 17$ & $52 \cdot 33$ & $15 \cdot 01$ \\
\hline 0.20 & 500 & 81.50 & 78.00 & 14.40 & $85 \cdot 34$ & 61.50 & 63.33 & 53.41 \\
\hline 0.20 & 1000 & 83.83 & $83 \cdot 17$ & 14.58 & $85 \cdot 83$ & 64.33 & $65 \cdot 17$ & 54.83 \\
\hline 0.40 & 0 & 77.69 & 75.04 & 13.54 & 80.50 & $53 \cdot 17$ & 52.50 & $15 \cdot 84$ \\
\hline 0.40 & 500 & 81.67 & $80 \cdot 17$ & 14.48 & 85.67 & 59.17 & 64.00 & $50 \cdot 85$ \\
\hline 0.40 & 1000 & $83 \cdot 17$ & 78.17 & 14.57 & $86 \cdot 51$ & $62 \cdot 00$ & $62 \cdot 67$ & 53.67 \\
\hline SEM & & 1.08 & 0.79 & 0.03 & 0.63 & 0.71 & 0.75 & 0.83 \\
\hline \multicolumn{9}{|l|}{ Main effect $\dagger$} \\
\hline \multicolumn{9}{|l|}{ Phytate P } \\
\hline $0 \cdot 20 \%$ & & 81.33 & 78.95 & $14 \cdot 19$ & 84.61 & 61.33 & $60 \cdot 28$ & 41.08 \\
\hline $0.40 \%$ & & $80 \cdot 84$ & 77.79 & $14 \cdot 20$ & 84.23 & $58 \cdot 11$ & $59 \cdot 72$ & $40 \cdot 12$ \\
\hline$P \leq$ & & NS & NS & NS & NS & 0.001 & NS & NS \\
\hline \multicolumn{9}{|l|}{ Phytase } \\
\hline 0 & & 78.18 & $75 \cdot 36$ & 13.56 & 81.58 & $55 \cdot 67$ & 52.42 & 15.43 \\
\hline 500 & & 81.59 & 79.09 & 14.44 & $85 \cdot 51$ & $60 \cdot 34$ & 63.67 & $52 \cdot 13$ \\
\hline 1000 & & 83.50 & $80 \cdot 67$ & 14.58 & $86 \cdot 17$ & $63 \cdot 17$ & 63.92 & 54.25 \\
\hline$P \leq$ & & 0.001 & 0.001 & 0.001 & 0.001 & 0.001 & 0.001 & 0.001 \\
\hline \multicolumn{9}{|c|}{ Phytase $\times$ phytate } \\
\hline$P \leq$ & & NS & 0.001 & NS & NS & NS & NS & NS \\
\hline
\end{tabular}

FTU, phytase unit; $\mathrm{CP}$, crude protein; $\mathrm{DE}$, digestible energy; $\mathrm{EE}$, crude fat; NS, $P \geq 0.05$

${ }^{*} n 6$ per treatment.

† Data involving 0.20 or $0.40 \%$ phytate phosphorus with 0,500 or $1000 \mathrm{FTU} / \mathrm{kg}$ microbial phytase were analysed as a $2 \times 3$ factorial arrangement of treatments. 
Table 5. Effect of phytate and phytase on the lipase activity in the pancreas and intestinal mucosa and the relative weight of pancreas of broiler chickens

\begin{tabular}{|c|c|c|c|c|c|c|}
\hline \multicolumn{2}{|l|}{ Treatment* } & \multicolumn{4}{|c|}{ Lipase activity } & \multirow[b]{2}{*}{$\begin{array}{l}\text { PW:BW } \\
\text { (g:g) }\end{array}$} \\
\hline $\begin{array}{l}\text { Phytate P } \\
(\%)\end{array}$ & $\begin{array}{l}\text { Phytase } \\
\text { (FTU/kg) }\end{array}$ & $\begin{array}{l}\text { Pancreas } \\
\text { ( } \mu \mathrm{mol} / \mathrm{g} \text { protein) }\end{array}$ & $\begin{array}{l}\text { Duodenum } \\
\text { ( } \mu \mathrm{mol} / \mathrm{g} \text { protein) }\end{array}$ & $\begin{array}{l}\text { Jejunum } \\
\text { ( } \mu \mathrm{mol} / \mathrm{g} \text { protein) }\end{array}$ & $\begin{array}{l}\text { Ileum } \\
\text { ( } \mu \mathrm{mol} / \mathrm{g} \text { protein) }\end{array}$ & \\
\hline 0.20 & 0 & 1.96 & $1 \cdot 13$ & 0.89 & 0.37 & 0.42 \\
\hline 0.20 & 500 & 2.02 & $1 \cdot 12$ & 0.91 & 0.38 & 0.44 \\
\hline 0.20 & 1000 & 2.03 & $1 \cdot 19$ & 0.89 & 0.36 & 0.45 \\
\hline 0.40 & 0 & 1.79 & 0.94 & 0.83 & 0.34 & 0.40 \\
\hline 0.40 & 500 & 1.98 & $1 \cdot 10$ & 0.84 & 0.35 & 0.45 \\
\hline 0.40 & 1000 & 1.93 & 1.08 & 0.79 & 0.33 & 0.43 \\
\hline SEM & & 0.04 & 0.02 & 0.01 & 0.02 & 0.02 \\
\hline \multicolumn{7}{|c|}{ Main effect† } \\
\hline \multicolumn{7}{|c|}{ Phytate P } \\
\hline 0.20 & & 2.00 & $1 \cdot 15$ & 0.90 & 0.37 & 0.44 \\
\hline 0.40 & & 1.90 & 1.04 & 0.82 & 0.34 & 0.43 \\
\hline$P \leq$ & & 0.036 & 0.002 & 0.002 & 0.002 & NS \\
\hline \multicolumn{7}{|l|}{ Phytase } \\
\hline 0 & & $1 \cdot 88$ & 1.04 & 0.86 & 0.36 & 0.41 \\
\hline 500 & & $2 \cdot 00$ & $1 \cdot 11$ & 0.88 & 0.37 & 0.45 \\
\hline 1000 & & 1.98 & $1 \cdot 14$ & 0.84 & 0.35 & 0.44 \\
\hline$P \leq$ & & NS & NS & NS & NS & 0.006 \\
\hline \multicolumn{7}{|c|}{ Phytase $\times$ phytate } \\
\hline$P \leq$ & & NS & NS & NS & NS & NS \\
\hline
\end{tabular}

FTU, phytase unit; PW, pancreas weight; BW, body weight; NS, $P \geq 0.05$.

${ }^{*} n 6$ per treatment; data were from the pools of pancreas and intestinal mucosa by cage.

†Data involving 0.20 or $0.40 \%$ phytate phosphorus with 0,500 or $1000 \mathrm{FTU} / \mathrm{kg}$ microbial phytase were analysed as a $2 \times 3$ factorial arrangement of treatments.

(Table 7). Phytate by phytase on the mRNA expression of FASN was significant $(P<0 \cdot 05)$. Phytase up-regulated $(P<0 \cdot 01)$ the mRNA expression of FASN by 25 and $37 \%$ in the low and high phytate basal diets, respectively, but down-regulated $(P<0.05)$ the mRNA expression of leptin by 74 and $71 \%$ in the low and high phytate basal diets, respectively. Dietary phytate also reversely influenced $(P<0.05)$ the mRNA expressions of FASN and leptin when no phytase was added. Increasing dose rates of phytase had no effect $(P>0.05)$ on the mRNA expression of FASN and leptin in the liver of broilers.

\section{Discussion}

In the present study, sodium phytate was used to manipulate the phytate $\mathrm{P}$ content of diets, and showed a significant

Table 6. Effect of phytate and phytase on the metabolism of lipid in the serum and liver of broiler chickens

\begin{tabular}{|c|c|c|c|c|c|c|c|c|c|}
\hline \multicolumn{2}{|l|}{ Treatment* } & \multicolumn{5}{|c|}{ Serum } & \multicolumn{3}{|c|}{ Liver } \\
\hline $\begin{array}{l}\text { Phytate P } \\
(\%)\end{array}$ & $\begin{array}{l}\text { Phytase } \\
\text { (FTU/kg) }\end{array}$ & $\begin{array}{l}\text { NEFA } \\
(\mathrm{mmol} / \mathrm{l})\end{array}$ & $\begin{array}{c}\text { TAG } \\
(\mathrm{mmol} / \mathrm{l})\end{array}$ & $\begin{array}{l}\mathrm{T}-\mathrm{CHO} \\
(\mathrm{mmol} / \mathrm{l})\end{array}$ & $\begin{array}{l}\text { HDLC } \\
(\mathrm{mmol} / \mathrm{l})\end{array}$ & $\begin{array}{l}\text { LDLC } \\
(\mathrm{mmol} / \mathrm{l})\end{array}$ & $\begin{array}{c}\text { NEFA } \\
(\mu \mathrm{mol} / \mathrm{g} \text { protein })\end{array}$ & $\begin{array}{c}\text { TAG } \\
(\mu \mathrm{mol} / \mathrm{g} \text { protein })\end{array}$ & $\begin{array}{c}\mathrm{T}-\mathrm{CHO} \\
\text { ( } \mu \mathrm{mol} / \mathrm{g} \text { protein) }\end{array}$ \\
\hline 0.20 & 0 & 0.55 & 0.83 & 2.99 & 0.80 & $1 \cdot 27$ & $124 \cdot 34$ & $37 \cdot 34$ & $134 \cdot 77$ \\
\hline 0.20 & 500 & 0.42 & 0.82 & 3.63 & 0.85 & 1.60 & $86 \cdot 82$ & $45 \cdot 83$ & 86.54 \\
\hline 0.20 & 1000 & 0.47 & 0.81 & $3 \cdot 23$ & 0.83 & $1 \cdot 30$ & 57.09 & 43.59 & $67 \cdot 07$ \\
\hline 0.40 & 0 & 0.72 & 0.76 & $2 \cdot 85$ & 0.89 & $1 \cdot 17$ & 154.90 & $37 \cdot 88$ & $132 \cdot 18$ \\
\hline 0.40 & 500 & 0.61 & 0.82 & $3 \cdot 12$ & 0.86 & 1.49 & $76 \cdot 26$ & 41.99 & $84 \cdot 78$ \\
\hline 0.40 & 1000 & 0.66 & 0.83 & $3 \cdot 11$ & 0.85 & 1.43 & $76 \cdot 04$ & $41 \cdot 23$ & 83.01 \\
\hline SEM & & 0.04 & 0.01 & 0.10 & 0.02 & 0.04 & 4.43 & $1 \cdot 32$ & $4 \cdot 10$ \\
\hline \multicolumn{10}{|c|}{ Main effect† } \\
\hline \multicolumn{10}{|c|}{ Phytate P } \\
\hline 0.20 & & 0.48 & 0.82 & $3 \cdot 28$ & 0.83 & $1 \cdot 39$ & $89 \cdot 42$ & $42 \cdot 25$ & $96 \cdot 13$ \\
\hline 0.40 & & 0.66 & 0.80 & 3.03 & 0.87 & $1 \cdot 36$ & $102 \cdot 40$ & $40 \cdot 37$ & 99.99 \\
\hline$P \leq$ & & 0.001 & NS & 0.005 & 0.010 & 0.043 & 0.001 & NS & NS \\
\hline \multicolumn{10}{|l|}{ Phytase } \\
\hline 0 & & 0.64 & 0.80 & 2.92 & 0.85 & $1 \cdot 22$ & 139.62 & $37 \cdot 61$ & $133 \cdot 48$ \\
\hline 500 & & 0.52 & 0.82 & $3 \cdot 38$ & 0.86 & 1.55 & 81.54 & 43.91 & $85 \cdot 66$ \\
\hline 1000 & & 0.57 & 0.82 & $3 \cdot 17$ & 0.84 & $1 \cdot 37$ & $66 \cdot 57$ & $42 \cdot 41$ & $75 \cdot 04$ \\
\hline$P \leq$ & & 0.024 & NS & 0.001 & NS & 0.001 & 0.001 & 0.001 & 0.001 \\
\hline \multicolumn{10}{|c|}{ Phytase $\times$ phytate } \\
\hline$P \leq$ & & NS & 0.002 & NS & NS & 0.009 & 0.001 & NS & 0.047 \\
\hline
\end{tabular}

FTU, phytase unit; T-CHO, total cholesterol; HDLC, HDL cholesterol; LDLC, LDL cholesterol; NS, $P \geq 0.05$.

${ }^{*} n 6$ per treatment.

† Data involving 0.20 or $0.40 \%$ phytate phosphorus with 0,500 or $1000 \mathrm{FTU} / \mathrm{kg}$ microbial phytase were analysed as a $2 \times 3$ factorial arrangement of treatments. 
Table 7. Effect of phytate and phytase on the mRNA expression of fatty acid synthase (FASN) and leptin in the liver of broiler chickens

\begin{tabular}{lcccc}
\hline \multicolumn{1}{l}{ Treatment* $^{*}$} & & & \\
\cline { 1 - 2 } Phytate P (\%) & Phytase (FTU/kg) & & FASN & Leptin \\
\hline 0.20 & 0 & 1.23 & 0.47 \\
0.20 & 500 & 1.50 & 0.37 \\
0.20 & 1000 & 1.57 & 0.33 \\
0.40 & 0 & 1.06 & 0.56 \\
0.40 & 500 & 1.44 & 0.40 \\
0.40 & 1000 & 1.47 & 0.40 \\
SEM & & 0.03 & 0.02 \\
Main effect† & & & \\
Phytate P & & 1.43 & 0.39 \\
0.20 & & 1.32 & 0.45 \\
0.40 & & 0.001 & 0.001 \\
$P \leq$ & & & \\
Phytase & & 1.15 & 0.52 \\
0 & & 1.47 & 0.39 \\
500 & & 1.52 & 0.37 \\
1000 & & 0.001 & 0.001 \\
$P \leq$ & & & \\
Phytase $\times$ phytate & & 0.028 & NS \\
$P \leq$ & & & \\
\hline
\end{tabular}

FTU, phytase unit; NS, $P \geq 0.05$.

* $n 6$ per treatment; mRNA expression was the pool of six chicken livers by cage, expressed as initial copies normalised to $\beta$-actin copies using real-time PCR.

†Data involving 0.20 or $0.40 \%$ phytate with 0,500 or $1000 \mathrm{FTU} / \mathrm{kg}$ microbial phytase were analysed as a $2 \times 3$ factorial arrangement of treatments.

negative effect on the feed per gain, which is the same effect by natural phytate, such as rice bran, on the growth performance of broiler chickens ${ }^{(2,3)}$. The effect of sodium phytate on the digestibility of most nutrients had no significance, except for the digestibility of $\mathrm{Ca}$. This is inconsistent with the study by Ravindran et al. ${ }^{(8)}$ who reported that diets containing $0.38 \%$ phytate $\mathrm{P}$ (fed as the rice bran) reduced the ileal digestibility of metabolisable energy and crude protein of broiler starters. When no phytase was added in the present study, increasing phytate P from 0.20 to $0.40 \%$ decreased the digestibility of crude fat, which is supported by the work that dietary increased the amounts of faecal total lipid, TAG and T-CHO in mice ${ }^{(7)}$. Additionally, the digestibility of crude protein in the diet with phytase at 500 phytase units/kg was higher than 1000 phytase units/kg in the high phytate basal diets in the present study, which is an unexpected observation and difficult to explain.

The matrix value of phytase in the energy utilisation in broilers has been recently reported in a number of studies ${ }^{(2,3,9,10)}$. However, dietary lipids as an important source of energy and contributing to the energy digestibility parameter, how it is affected by phytase is limitedly reported in broiler chickens. Only Camden et al. ${ }^{(10)}$ reported that phytase increased the digestibility of fat by $3.4 \%$ in broiler starters. This is similar to the result in the present study that phytase enhanced the fat digestibility from 81.6 to $85.8 \%$ in broiler finishers. In general, the effect of sodium phytate on the growth and nutrient digestibility of broilers in the present study was not as expected, which may be caused from the differences in the chemical structure and feature between sodium phytate and natural phytate in grains and legumes, because sodium phytate is lack of linkage to other nutrients, such as protein, fat and starch.

As noted previously, phytate is capable of depressing enzymatic digestion of proteins and carbohydrates both in vitro ${ }^{(16-19)}$ and in vivo ${ }^{(2,3,20)}$. The underlying mechanisms by which phytate inhibits the activity of digestive enzyme in the gastrointestinal tract of animals may include the chelation with cofactors required for optimum enzyme activity, such as $\mathrm{Ca}^{2+}$, or forming phytate- $\mathrm{Ca}^{2+}$-protein complexes ${ }^{(16)}$. Knuckles $^{(4)}$ reported that phytate at $4 \mathrm{~mm}$ and 1,2-monophosphate at $12 \mathrm{~mm}$ caused significant inhibition on the in vitro activity of porcine pancreatic lipase by 14.5 and $8.2 \%$, respectively, and the isolated inositol phosphate ester fractions also significantly lowered the activity of lipase, and the decrease in enzymatic activity was highly correlated with the degree of inositol phosphorylation. However, there is little literature regarding the effect of phytate on the in vivo activity of lipase in animals. In the present study, dietary phytate significantly decreased the activity of lipase by $7-20 \%$, indicating that phytate may mediate the lipid digestion and subsequently energy utilisation. Microbial phytase compensated the adverse effect of phytate on enzymatic activity and also improved the relative weight of pancreas, but the augment on the relative weight of pancreas by phytase seemed to be unusual and needs further study.

In the present study, it is interesting that dietary sodium phytate decreased the levels of serum T-CHO and LDL cholesterol, and increased serum NEFA and HDLC, and hepatic NEFA of chickens. Although little is known about the effect of dietary phytate on lipids profiles in chickens or other farm animals, there are some related reports on mice or rats. Lee et al. ${ }^{(7,21)}$ reported that dietary phytate decreased the concentrations of serum and T-CHO and LDL cholesterol, hepatic TAG and $\mathrm{T}-\mathrm{CHO}$, and the apparent absorption rates of total lipid and cholesterol, and increased serum HDLC levels in mice. Szkudelski ${ }^{(6)}$ reported that consumption of food with increased amounts of phytic acid $(0 \cdot 1,0 \cdot 2,0 \cdot 3$ and $1 \%)$ resulted in a substantial reduction in hepatic TAG, but serum TAG were unaffected in rats. Simultaneously, the serum NEFA levels were decreased in the groups with phytic acid at 0.1 and $0.2 \%$, but not be observed in the highest group ${ }^{(6)}$.

In contrast, some studies reported that phytate had no significant effect on altering blood lipids in human subjects ${ }^{(22)}$ and lipid digestion in rats ${ }^{(23)}$, presumably because the content of phytate in the diet was too low to cause differences. In the present study, the changes in the concentrations of lipid profiles in the serum and liver indicated that phytate can interfere with lipid metabolism, and consequently energy regulation including energy ingestion and body lipid deposition of chickens. Interestingly, the inclusion of phytase can modify the levels of most lipids profiles in serum and liver of chickens, suggesting that phytase may contribute to the lipid metabolism and body fat synthesis.

Given the evidence that dietary phytate reduced the levels of blood and hepatic lipid in mice ${ }^{(7,21)}$, rats $^{(6,24)}$ and chickens ${ }^{(25)}$, it is putative that phytate should influence the activity of lipogenic enzyme. Indeed, in the present study, dietary phytate significantly reduced the mRNA expression of FASN, indicating that phytate interferes with the synthesis of body lipid. Dilworth et al. ${ }^{(24)}$ found that dietary phytate did not influence the activity of malic enzyme, ATP-citrate lyase, pyruvate kinase and 6-phosphogluconate dehydrogenase, but increased the activity of glucose-6-phosphate dehydrogenase. Additionally, phytate depressed the activity of carbohydrase ${ }^{(2)}$ and lipase, which consequently caused the decrease in the digestion of carbohydrates and lipids, and the concentrations of dihydroxyacetone 
phosphate, glucose and TAG, coupled with the decrease in the synthesis of $\operatorname{ATP}^{(25-27)}$. The reduction in the concentration of materials for lipid synthesis implicates that phytate may weaken the synthesis of hepatic and body lipid.

Peripheral signals of energy status is the main path to the regulation of homeostatic mechanism of energy in the body ${ }^{(28)}$. Leptin is an important circulating signal that reduces appetite and adiposity stores of animals ${ }^{(29,30)}$. In the present study, phytate increased the mRNA expression of leptin in the liver, indicating that phytate can decrease the lipid store utilisation of broilers, and phytase reversely influenced the mRNA expression of leptin, indicating that phytase can enhance the body fat deposition.

In summary, the results of the present study suggest that dietary sodium phytate and microbial phytase can modify the digestibility of crude fat, biochemical activity of lipase and FASN, and the levels of lipids, leptin in the serum and liver, and consequently the digestion and deposition processes of fat for broiler chickens.

\section{Acknowledgements}

The present work was supported by the Initial Fund for Doctor of Natural Science Foundation of Henan University of Science and Technology. Professor S. Dong at Henan University of Science and Technology and Dr F. Li at Gansu Agricultural University are thanked for constructive discussions for the experimental design and assistance in measuring the biochemical parameters of the study. N. L. designed, conducted the study and wrote the manuscript. Y. R. freely offered the phytase and helped to design the study. J. W. and T. X. helped to conduct the experimental assay, collated all statistical information and revised the manuscript. All authors read and approved the findings of the study.

There are no conflicts of interest with any institute or commercial corporation on the present study.

\section{References}

1. Cowieson AJ \& Ravindran V (2007) Effect of phytic acid and phytase on the flow and amino acid composition of endogenous protein at the terminal ileum of growing broiler chickens. $\mathrm{Br} \mathrm{J}$ Nutr 98, 745-752.

2. Liu N, Ru YJ, Li FD, et al. (2008) Effect of diet containing phytate and phytase on the activity and mRNA expression of carbohydrase and transporter in chickens. J Anim Sci 86, 3432-3439.

3. Liu N, Ru YJ, Li FD, et al. (2009) Effect of dietary phytate and phytase on proteolytic digestion and growth regulation for Broilers. Arch Anim Nutr 63, 292-303.

4. Knuckles BE (1988) Effect of phytate and other myo-inositol phosphate esters on lipase activity. J Food Sci 53, 250-252.

5. Katayama T (1997) Effects of dietary myo-inositol or phytic acid on hepatic concentrations of lipids and hepatic activities of lipogenic enzymes in rats fed on corn starch or sucrose. Nutr Res 17, 721-728.

6. Szkudelski T (2005) Phytic acid-induced metabolic changes in the rat. J Anim Physiol Anim Nutr 89, 397-402.

7. Lee SH, Park HJ, Chun HK, et al. (2007) Dietary phytic acid improves serum and hepatic lipid levels in aged ICR mice fed a high-cholesterol diet. Nutr Res 27, 505-510.

8. Ravindran V, Morel PC, Partridge GG, et al. (2006) Influence of an Escherichia coli-derived phytase on nutrient utilization in broiler starters fed diets containing varying concentrations of phytic acid. Poult Sci 85, 82-89.

9. Cowieson AJ \& Adeola O (2005) Carbohydrases, protease, and phytase have an additive beneficial effect in nutritionally marginal diets for broiler chicks. Poult Sci 84, 1860-1867.

10. Camden BJ, Morel PCH, Thomas DV, et al. (2001) Effectiveness of exogenous microbial phytase in improving the bioavailabilities of phosphorus and other nutrients in maize-soya-bean meal diets for broilers. Anim Sci 73, 289-297.

11. Stubbs RJ (1999) Peripheral signals affecting food intake. Nutrtion 15, 614-625.

12. Short FJ, Gorton P, Wiseman J, et al. (1996) Determination of titanium dioxide added as inert marker in chicken digestibility studies. Anim Feed Sci Technol 59, 215-221.

13. Maga JA (1982) Phytate: its chemistry, occurrence, food interactions, nutritional significance, and methods of analysis. J Agric Food Chem 30, 1-9.

14. Iijima N, Tanaka S \& Ota Y (1998) Purification and characterization of bile salted-actvity lipase from the hepatopancreas of red seabream, Pagrus major. Fish Physiol Biochem 18, 59-69.

15. Lowry OH, Rosebrough NJ, Farr AL, et al. (1951) Protein measurement with the folin-phenol reagent. J Biol Chem 193, $265-275$.

16. Singh $M$ \& Krikorian AD (1982) Inhibition of trypsin activity in vitro by phytate. J Agric Food Chem 30, 799-800.

17. Deshpande SS \& Ceryan M (1984) Effects of phytic acid, divalent cations, and their interactions on $\alpha$-amylase activity. $J$ Food Sci 49, 516-519.

18. Knuckles BE \& Betschart AA (1987) Effect of phytate and other myo-inositol phosphate esters on $\alpha$-amylase digestion of starch. J Food Sci 52, 719-721.

19. Cawley RW \& Mitchell TA (1968) Inhibition of wheat alphaamylase by bran phytic acid. J Sci Food Agric 19, 106-108.

20. Dilworth LL, Omoruyi FO, Simon O, et al. (2004) Hypoglycemia and faecal minerals in rats fed phytate. Nutr Food Sci 34, $60-64$.

21. Lee SH, Park HJ, Cho SY, et al. (2005) Effects of dietary phytic acid on serum and hepatic lipid levels in diabetic KK mice. Nutr Res 25, 869-876.

22. Eengelman HM, Alekel DL, Hanson LN, et al. (2005) Blood lipid and oxidative stress responses to soy protein with isoflavones and phytic acid in postmenopausal women. Am J Clin Nutr 81, 590-596.

23. Yuangklang C, Wensing Th, Lemmens AG, et al. (2005) Effect of sodium phytate supplementation on fat digestion and cholesterol metabolism in female rats. J Anim Physiol Anim Nutr 89, 373-378.

24. Dilworth LL, Omoruyi FO \& Asemota HN (2005) Digestive and absorptive enzymes in rats fed phytic acid extract from sweet potato (Ipomoea batatas). Diabetol Croat 34, 59-65.

25. Liu N, Ru YJ \& Li FD (2009) Effect of dietary phytate and phytase on the metabolic change of blood and intestinal mucosa in chickens. J Anim Physiol Anim Nutr (In the Press).

26. Dilworth LL, Omoruyi FO, Simon OR, et al. (2005) The effect of phytic acid on the levels of blood glucose and some enzymes of carbohydrate and lipid metabolism. West Indian Med J 54, 102-106.

27. Lee SH, Park HJ, Chun HK, et al. (2006) Dietary phytic acid lowers the blood glucose level in diabetic KK mice. Nutr Res 26, 474-479.

28. Jequire E \& Tappy L (1999) Regulation of body weight in humans. Physiol Rev 79, 451-480.

29. Woods SC, Seeley RJ, Porte D, et al. (1998) Signals that regulate food intake and energy homeostasis. Science 280, $1378-1383$.

30. Williams J \& Mobarhan S (2003) A critical interaction: leptin and ghrelin. Nutr Rev 61, 391-393. 